by Mike Walker ${ }^{*}$, Martin J. Head ${ }^{2}$, Max Berkelhammer $^{3}$, Svante Björck ${ }^{4}$, Hai Cheng, Les Cwynar ${ }^{6}$, David Fisher ${ }^{7}$, Vasilios Gkinis ${ }^{8}$, Antony Long ${ }^{9}$, John Lowe ${ }^{10}$, Rewi Newnham ${ }^{11}$, Sune Olander Rasmussen ${ }^{8}$, and Harvey Weiss ${ }^{12}$

\title{
Formal ratification of the subdivision of the Holocene Series/ Epoch (Quaternary System/Period): two new Global Boundary Stratotype Sections and Points (GSSPs) and three new stages/ subseries
}

\author{
${ }^{1}$ School of Archaeology, History and Anthropology, Trinity Saint David, University of Wales, Lampeter, Wales SA48 7EJ, UK; Department of \\ Geography and Earth Sciences, Aberystwyth University, Aberystwyth, Wales SY23 3DB, UK; *Corresponding author, E-mail: m.walker@uwtsd.ac.uk \\ ${ }^{2}$ Department of Earth Sciences, Brock University, 1812 Sir Isaac Brock Way, St. Catharines, Ontario LS2 3A1, Canada \\ ${ }^{3}$ Department of Earth and Environmental Sciences, University of Illinois, Chicago, Illinois 60607, USA \\ ${ }^{4}$ GeoBiosphere Science Centre, Quaternary Sciences, Lund University, Sölveg 12, SE-22362, Lund, Sweden \\ ${ }^{5}$ Institute of Global Change, Xi'an Jiaotong University, Xian, Shaanxi 710049, China; Department of Earth Sciences, University of Minne- \\ sota, Minneapolis, MN 55455, USA \\ ${ }^{6}$ Department of Biology, University of New Brunswick, Fredericton, New Brunswick E3B 5A3, Canada \\ ${ }^{7}$ Department of Earth Sciences, University of Ottawa, Ottawa K1N 615, Canada \\ ${ }^{8}$ Centre for Ice and Climate, The Niels Bohr Institute, University of Copenhagen, Julian Maries Vej 30, DK-2100, Copenhagen, Denmark \\ ${ }^{9}$ Department of Geography, Durham University, Durham DH1 3LE, UK \\ ${ }^{10}$ Department of Geography, Royal Holloway, University of London, Egham TW20 0EX, UK \\ ${ }^{11}$ School of Geography, Environment and Earth Sciences, Victoria University of Wellington, Wellington 6012, New Zealand \\ ${ }^{12}$ School of Forestry and Environmental Studies, Yale University, New Haven, CT 06511, USA
}

(Received: August 13, 2018; Revised accepted: September 30, 2018)

https://doi.org/10.18814/epiiugs/2018/018016

The Holocene is probably the most intensively studied series/epoch within the geological record, and embodies a wide array of geomorphological, climatic, biotic and archaeological evidence; yet little attention has hitherto been paid to a formal subdivision of this series/epoch. Here we report a tripartite division of the Holocene into the Greenlandian, Northgrippian and Meghalayan stages/ages and their corresponding Lower/Early, Middle, Upper/Late subseries/subepochs, each supported by a Global Boundary Stratotype Section and Point (GSSP). The GSSP for the lowermost stage, the Greenlandian, is that of the Holocene as previously defined in the NGRIP2 Greenland ice core, and dated at 11,700 yr b2k (before 2000 CE). The GSSP for the Northgrippian is in the NGRIPI Greenland ice core, and dated at $8236 \mathrm{yr}$ b2k, whereas that for the Meghalayan is located in a speleothem from Mawmluh Cave, Meghalaya, northeast India with a date of $4250 \mathrm{yr}$ b2k. The proposal on which this subdivision is based was submitted by the Subcommission on Quaternary Stratigraphy, approved by the International Commission on Stratigraphy, and formally ratified by the Executive Committee of the International Union of Geological Sciences on $14^{\text {th }}$ June 2018.

\section{Introduction}

The Holocene is the uppermost chronostratigraphic unit within the geological record and covers the time interval from $11.7 \mathrm{ka}$ until the present day. The term 'holocènes', which means 'entirely recent', was first used by Paul Gervais (1867-69, p. 32) to refer to the warm episode that began with the end of the last glacial period, and which had previously been referred to as 'Recent' (Lyell, 1839) or 'Post-Glacial' (Forbes, 1846). It entered the international lexicon as 'holocènes' during the Second International Geological Congress (IGC) held in Bologna in 1882, and a 'Holocenian' Stage was proposed by the Portuguese Committee for the Third IGC in Berlin in 1885. The Holocene is now officially defined as a series/epoch within the Quaternary System/Period (Walker et al., 2008, 2009; Gibbard and Head, 2010; Gibbard et al., 2010; Head and Gibbard, 2015).

Holocene stratigraphic records provide evidence, inter alia, of climate and sea-level change, geomorphological and hydrological processes, vegetational developments, and faunal migrations. In addition, they contain a unique range and wealth of archaeological data that attest to the development of society and the evolving relationships between people and the environment under near modern boundary conditions. Holocene successions are often extremely well-preserved, continu- 
ous and amenable to examination at high temporal resolution. It is surprising, therefore, that relatively little attention has been paid, hitherto, to the formal subdivision of the Holocene, and particularly in view of recent initiatives in Quaternary stratigraphic subdivision and nomenclature (Cita et al., 2006, 2008, 2012; Head et al., 2008; Walker et al., 2008, 2009; Gibbard and Head, 2009, 2010; Gibbard et al., 2010; Head and Gibbard, 2015).

In 2010, a Working Group of the Subcommission on Quaternary Stratigraphy (SQS) and members of the INTIMATE (Integration of Ice Core, Marine and Terrestrial Records) Research Group was convened at the suggestion of Philip Gibbard, then chair of SQS, to consider this matter. Initial deliberations of the Group were set out in a position paper (Walker et al., 2012) and, in due course, a proposal was submitted to the International Commission on Stratigraphy (ICS) via the SQS. This outlined a formal subdivision of the Holocene into three stages/ages and their corresponding subseries/subepochs, each supported by a Global Boundary Stratotype Section and Point (GSSP). The proposal was approved by the ICS and subsequently ratified unanimously by the Executive Committee of the International Union of Geological Sciences (IUGS) on $14^{\text {th }}$ June 2018. Here we explain briefly the background to the proposal and present details on the new Holocene stages/ages and subseries/subepochs, and their associated GSSPs.

\section{Background and Context}

A formal subdivision of the Holocene was first outlined by Mangerud et al. (1974) who proposed that for Northern Europe, the Flandrian (regional) Stage (equivalent to the Holocene Series) should be divided into three substages with boundaries defined by radiocarbondated chronozones based on palynologically-defined biozones: Early Flandrian (Preboreal and Boreal: $10,000-8000{ }^{14} \mathrm{C} \mathrm{yr} \mathrm{BP}$ ); Middle Flandrian (Atlantic and Subboreal: $8000-2500{ }^{14} \mathrm{C}$ yr BP); and Late Flandrian (Sub-Atlantic: post $2500{ }^{14} \mathrm{C}$ yr BP). But time-transgression in vegetational response to climate change suggests that such a chronostratigraphic subdivision of the Holocene based on biological evidence is not applicable at anything other than the local or perhaps regional scale (Björck et al., 1998; Wanner et al., 2008). Nevertheless, the concept of a tripartite subdivision of the Holocene clearly has validity, with the terms 'Early', 'Middle' ('Mid-') and 'Late' Holocene being routinely applied in the Quaternary science literature. Yet, despite their common usage the precise temporal limits of each of these subdivisions has never been formally agreed.

One reason for this is that unlike earlier time intervals in the Quaternary, the Holocene contains few long-term climatic or environmental trends that register globally and that provide a basis for subdividing into distinct climatostratigraphic units. Hence any subdivision is best achieved through formalizing the subdivisions that are already being used ('Early', 'Middle' and 'Late Holocene') by underpinning them, where possible, with clearly defined marker horizons. These should ideally be globally applicable and should differentiate the Holocene Series/Epoch into three stages/ages and their corresponding subseries/

\footnotetext{
${ }^{1}$ Note that 'BP' here, as well as below, means 'before 1950', whereas icecore age estimates are reported using the designation 'b2k', i.e., relative to $2000 \mathrm{CE}$.
}

subepochs, based on distinct age boundaries defined by formally ratified GSSPs (Walker et al., 2012).

\section{The Case for Subseries/Subepochs in the Holocene}

Holocene stratigraphers use geochronology universally. Annual/ seasonal layering in ice cores, speleothems, and lacustrine and anoxic marine records, along with growth bands in shells, corals and wood, all provide ages by direct counting from the present (Head et al., 2017). The base of the Holocene itself is dated in exactly this way (Walker et al., 2009). In addition, a wide range of geochronometric methods is used routinely in the dating of Holocene sedimentary successions, including radiocarbon, uranium series, lead-210 and thermoluminescence dating, all of which give age estimates in years before present (or a proxy for the present). These methods of dating are more precise and reliable than traditional means of stratigraphic correlation. Consequently, Holocene records typically show data relative to a timescale in years, not core or sediment depth. Accordingly, it is natural to use the terms 'Early', 'Middle' and 'Late' for Holocene records (Head et al., 2017). Although subseries/subepochs have always been acceptable under the International Stratigraphic Guide (Hedberg, 1976: table 2; Salvador 1994; table 3), in practice this rank has not been sanctioned by the IUGS. But the terminology is pervasive in the literature of the Quaternary, and especially of the Holocene, and hence it is entirely appropriate that while the new subdivisions described here are formally designated as stages and ages, they are formally accompanied by their corresponding subseries and subepochs.

\section{The Ratified GSSPs}

We report two new GSSPs, one in an ice core and one in a cave deposit (a speleothem). While both of these might be seen as unconventional media for GSSPs, there are good reasons why they have been chosen. The precedent for using an ice core as a GSSP was set with the formal ratification of the Pleistocene-Holocene boundary in the Greenland NorthGRIP2 (NGRIP2) ice core (Walker et al., 2008, 2009), and so the designation here of a GSSP based on stable isotope records in an ice core follows previously established practice. The use of a speleothem, on the other hand, is new. It is justified by the fact that speleothems (a) are stratified successions that occur in most terrestrial regions on Earth; (b) can be analysed at unusually high levels of stratigraphic resolution (sub-decadal to annual); and (c) contain a stable isotopic record that can be underpinned by a high-precision chronology based on U-Th dating. The stable isotope profile in Holocene speleothem calcite has been shown to be an extremely sensitive proxy for climate (e.g., Cheng et al., 2009; Wu et al., 2012; Cheng et al., 2015), and thus dated shifts in the isotopic signal provide a highly detailed and chronologically precise record of Holocene climate change. As such, speleothems are unique yet widespread geological archives and, especially in the Holocene, constitute highly detailed stratigraphic successions and hence potential contexts for GSSPs. 


\section{The Greenlandian Stage/Age; Lower/Early Holocene Sub- series/Subepoch}

The Greenlandian Stage/Age is named with reference to the central Greenland ice sheet, where the North Greenland Ice Core project (NGRIP: Fig. 1) core was drilled to bedrock in $2003\left(75.10^{\circ} \mathrm{N} ; 42.32^{\circ} \mathrm{W}\right)$. The GSSP defining the base of the stage/age and corresponding subseries/subepoch is located at $1492.45 \mathrm{~m}$ in the NGRIP2 ice core, and was ratified as the base of the Holocene Series/Epoch in 2008. It has an estimated age of 11,700 yr b2k (before $2000 \mathrm{CE}$; Walker et al., 2008, 2009). This GSSP now also defines the base of the Greenlandian Stage/ Age, and the base of the Lower/Early Subseries/Subepoch, as the lowest stage and subseries of the Holocene. The primary marker for this GSSP in the NGRIP2 ice core is an abrupt shift to lower deuterium excess values, reflecting reorganisation of the evaporation regime at the precipitation source at the end of the Greenland Stadial 1/Younger Dryas Stadial. Together with changes in dust load and other parameters, the GSSP marks the first signs of a fundamental change in the climate

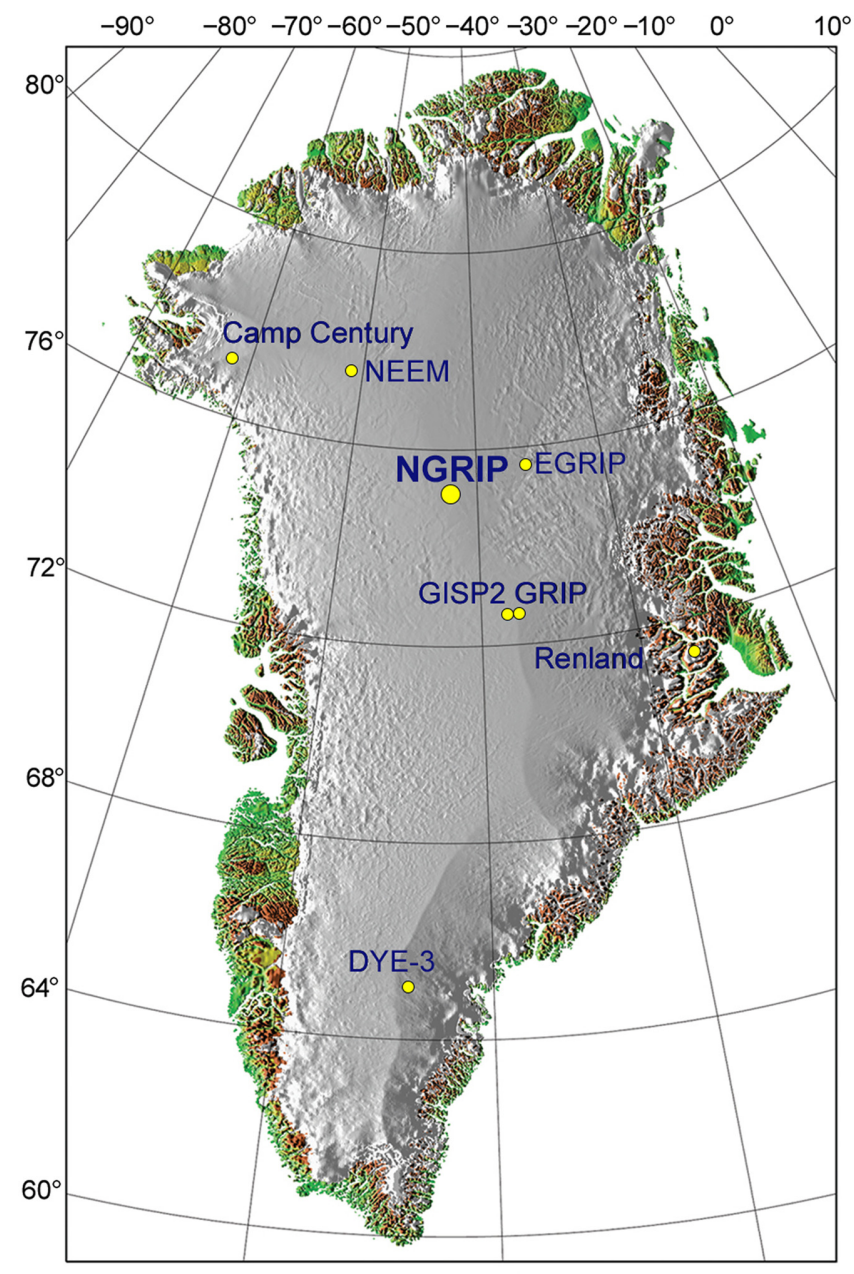

Figure 1. Location of the NorthGRIP coring site on the Greenland ice sheet, which serves as the type locality for the Greenlandian and Northgrippian stages/ages and their corresponding Lower/Early and Middle Holocene subseries/subepochs. Also shown are other deep drill sites, including GRIP and DYE-3 cores used in the construction of the GICC05 time scale upon which the chronology of the NGRIP1 and NGRIP2 records are based. and circulation patterns of Greenland and its surrounding areas (Steffensen et al., 2008). The NGRIP2 ice core is curated at the University of Copenhagen (Walker et al., 2008, 2009). The upper boundary of the Greenlandian Stage/Age and the Lower/Early Holocene Subseries/Subepoch is defined by the GSSP of the superjacent Northgrippian Stage/Age.

\section{The Northgrippian Stage/Age; Middle Holocene Subseries/ Subepoch}

The Northgrippian Stage/Age (corresponding to the Middle Holocene Subseries/Subepoch) is named with reference to the NGRIP1 ice core from central Greenland $\left(75.10^{\circ} \mathrm{N} ; 42.32^{\circ} \mathrm{W}\right)$ which is the type section for the GSSP. It is defined in the ice core at a depth of 1228.67 $\mathrm{m}$ at an interval that shows a clear signal of climatic cooling following a period of generally rising temperatures during the Early Holocene (Fig. 2). This cooling occurs around $8.2 \mathrm{ka}$ in the NGRIP1 core and corresponds with the ' 8.2 ka climatic event', a short-lived, near global episode that is reflected in a wide range of proxy climate records (see below). It is generally considered to reflect curtailment of North Atlantic Deep Water (NADW) formation and its associated northward heat transport, due to catastrophic meltwater release from glacial lakes Agassiz and Ojibway into the North Atlantic during wastage of the Laurentide Ice Sheet (Alley and Ágústdóttir, 2005; Kleiven et al., 2008; Hoffman et al., 2012), perhaps accompanied by collapse and accelerated melting of ice domes over Hudson Bay (Matero et al., 2017). The stratigraphic signature of the $8.2 \mathrm{ka}$ event therefore serves as the primary correlation event for the GSSP of the Northgrippian Stage/Age and Middle Holocene Subseries/Subepoch in the Greenland NGRIP1 ice core.

In the Greenland NGRIP1 ice core, the $8.2 \mathrm{ka}$ event is marked by a significant shift in the oxygen isotope record to more negative $\delta^{18} \mathrm{O}$ and $\delta \mathrm{D}$ values, reflecting abrupt cooling (Fig. 2), and by a decline in icecore annual layer thickness (Rasmussen et al., 2007) and deuterium excess (Masson-Delmotte et al., 2005). The water isotope diffusionderived temperature record indicates a cooling of $\sim 5^{\circ} \mathrm{C}$ (Gkinis et al., 2014). Within the $\delta^{18} \mathrm{O}$ minimum that constrains this event, there is also a strong volcanic signal marked by a double acidity peak reflected in electrical conductivity measurements (ECM). This layer, at 1228.67 $m$ depth in the NGRIP1 core (Fig. 3), is characterized by high fluoride content and can most likely be attributed to an Icelandic volcano. While it has not been linked to a specific eruption, the layer is found in all deep Greenland ice cores (Rasmussen et al., 2006; Vinther et al., 2006; see below). Moreover, while the climate signal inferred from the oxygen isotope record allows the GSSP to be placed within the coldest part of the $8.2 \mathrm{ka}$ event in the NGRIP1 core, examination of other proxy climate records shows that the $8.2 \mathrm{ka}$ event is part of a longer term episode of climate cooling (Rohling and Pälike, 2005; see below), and hence the use of the independent volcanic signal enables the GSSP to be located with a high degree of precision in the NGRIP1 ice core record.

The $8.2 \mathrm{ka}$ event is most strongly registered in localities around the North Atlantic Ocean (e.g., Snowball et al., 2010; Cohen and Hijma, 2014; Holmes et al., 2016), and therefore the Greenland NGRIP1 ice core is an appropriate high-latitude stratotype (GSSP). However, proxy climate records from other parts of the world also show anomalies 


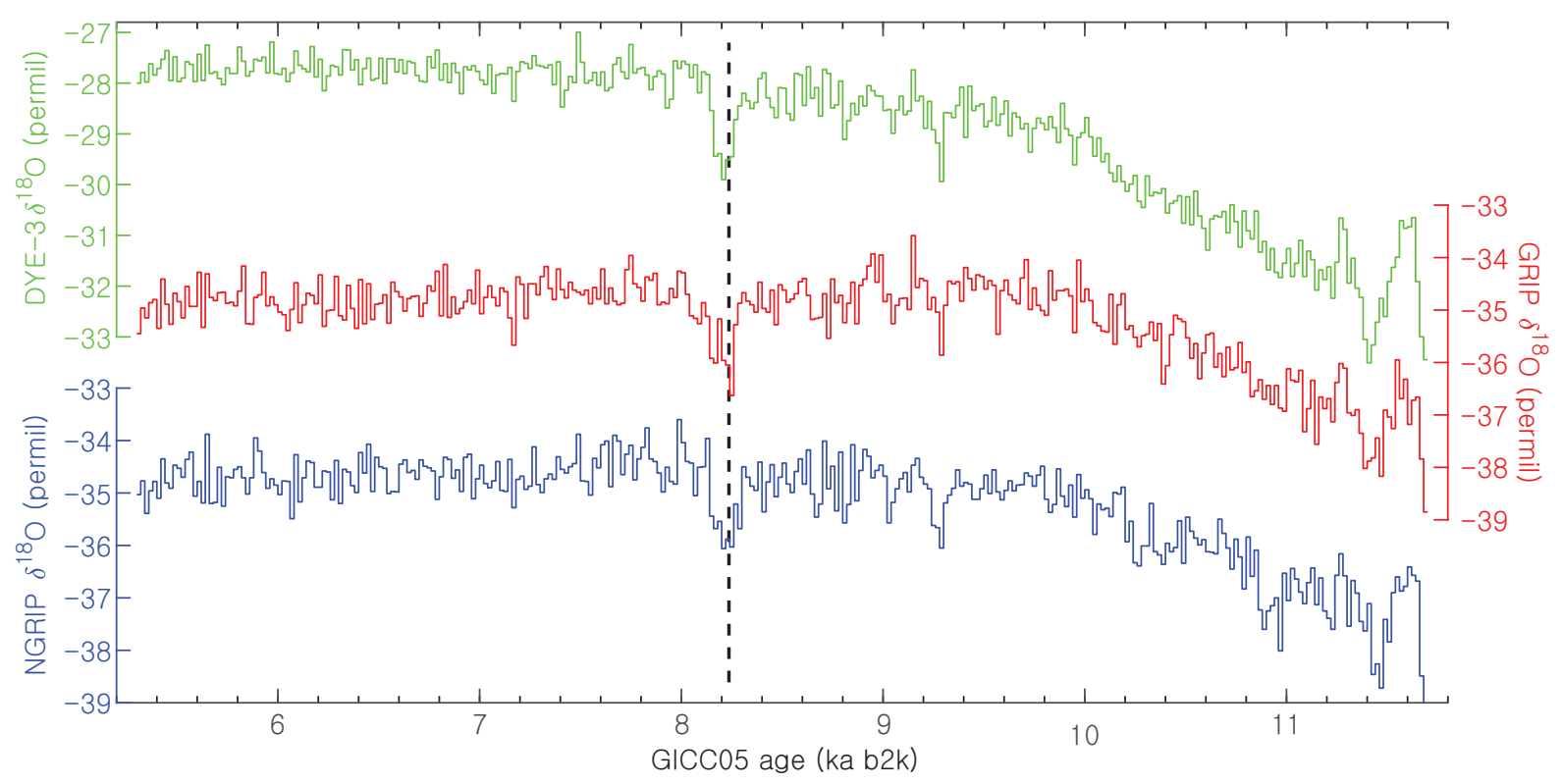

Figure 2. Water stable isotope ratios $\left(\delta^{18} \mathrm{O}\right)$ at 20-year resolution in three Greenland ice core records, DYE-3, GRIP and NGRIP (NGRIPI and NGRIP2 combined), over the time interval 11.7-5.3 ka b2k (before $2000 \mathrm{CE}$ ) on the GICC05 time scale (Rasmussen et al., 2006; Vinther et al., 2006). The location of the Early-Middle Holocene boundary inside the 8.2 ka event is shown by the dashed black line. Note that the $\delta^{18} \mathrm{O}$ records are aligned using the volcanic matching of the records. Differences in expression of the 8.2 ka event in the stable isotope records represent real differences in the isotope signal, and not dating or matching uncertainty.

around $8.2 \mathrm{ka}$, including those from speleothems in southern Asia, China, Brazil and California (Cheng et al., 2009; Wu et al., 2012; Oster et al., 2017); lake sequences in the Levant (Vossel et al., 2018), tropical Africa (Gasse, 2000), northern India (Dixit et al., 2014) and the Tibetan Plateau (Zhang and Mischke, 2009); pollen records from the Mediterranean (Pross et al., 2009; Peyron et al., 2011); ice cores from eastern Africa (Thompson et al., 2002); pollen data from Siberia (Velichko et al., 1997); tidal flat sediments from China (Chen et al., 2015); and marine records from the north-west Pacific (Hua et al., 2008). The $8.2 \mathrm{ka}$ event may also be recorded in lake sediment successions in East Antarctica (Cremer et al., 2007) and New Zealand (Augustinus et al., 2008). The 8.2 ka event is therefore near global in nature (Rohling and Pälike, 2005) and, as such, constitutes an ideal time-stratigraphic marker horizon for defining the base of the Northgrippian Stage/Age and the Lower/Early Holocene Subseries/Subepoch.

The age of the GSSP is derived from annual ice layer counting (the GICC05 timescale) using a range of physical and chemical parameters many of which vary seasonally, thereby enabling annual ice layers to be determined with a high degree of precision. These include dust concentration, conductivity of ice and melted samples, $\delta^{18} \mathrm{O}$ and $\delta \mathrm{D}$, and a range of chemical species including $\mathrm{Ca}^{2+}, \mathrm{NH}^{4+}, \mathrm{NO}^{3-}, \mathrm{Na}^{+}$and $\mathrm{SO}_{4}{ }^{2-}$ (Rasmussen et al., 2006; Vinther et al., 2006). In the upper levels of Greenland ice cores, annual ice layers can be readily identified on the basis of $\delta^{18} \mathrm{O}$ and $\delta \mathrm{D}$ records and seasonal variations in ice chemistry (Meese et al., 1997; Vinther et al., 2006). However, because of the relatively low accumulation rate at the drill site and a high sensitivity of the annual cycles in $\delta^{18} \mathrm{O}$ and $\delta \mathrm{D}$ to diffusion, NGRIP1 $\delta^{18} \mathrm{O}$ and $\delta \mathrm{D}$ data are not suitable for the identification of annual ice layers. In order to obtain a complete Holocene chronology for NGRIP1, therefore, the Early Holocene record was linked with that from other Greenland core sites, DYE-3 and GRIP (Fig. 1). The former is located in southeastern Greenland where a higher ice accumulation rate has produced the best resolved of all the Greenland ice-core timescales for the Middle and Late Holocene (Vinther et al., 2006). A key feature in all of the ice cores is the $8.2 \mathrm{ka}$ event which, as in NGRIP1, is marked by a reduction in $\delta \mathrm{D}$, by a prominent ECM double peak and by a marked increase in fluoride content reflecting a volcanic event (see above). Collectively, these features constitute a unique time-parallel marker horizon for correlating all Greenland ice-core records.

In the DYE-3 core, the annual layer situated in the middle of the ECM double peak is dated to $8236 \mathrm{yr}$ b2k with a maximum counting error of $47 \mathrm{yr}$ (Vinther et al., 2006) ${ }^{2}$. Note that the term b2k, which refers to the ice-core zero age of $2000 \mathrm{CE}$, is 50 years later than the zero year for radiocarbon which is $1950 \mathrm{CE}$; hence the equivalent age on the calibrated radiocarbon timescale is 8186 cal. yr BP. Accordingly, the GSSP for the Northgrippian Stage/Age and Middle Holocene Subseries/ Subepoch is defined at a depth of $1228.67 \mathrm{~m}$ in the Greenland NGRIP1 ice core with an age of $8236 \mathrm{yr}$ b2k.

In order to examine the stratotype horizons for the Greenlandian and Northgrippian stages/ages, deep ice-coring is necessary. However, the NGRIP1 and NGRIP2 cores are archived at the Centre for Ice and Climate, The Niels Bohr Institute, University of Copenhagen, Denmark, and access to these can be gained through the NGRIP curator (currently

${ }^{2}$ The uncertainty estimate of the GICC05 timescale is derived from the number of potential annual layers that the investigators found difficult to interpret. These layers were counted as $1 / 2 \pm 1 / 2 \mathrm{yr}$, and the so-called maximum counting error (mce) is defined as one half times the number of these features. Strictly speaking, the value of the mce cannot be interpreted as a standard Gaussian uncertainty estimate, but it is estimated that the true age of the base of the Northgrippian is within $\pm 47 \mathrm{yr}$ of $8236 \mathrm{yr} \mathrm{b} 2 \mathrm{k}$ with more than $95 \%$ probability (Andersen et al., 2006). 


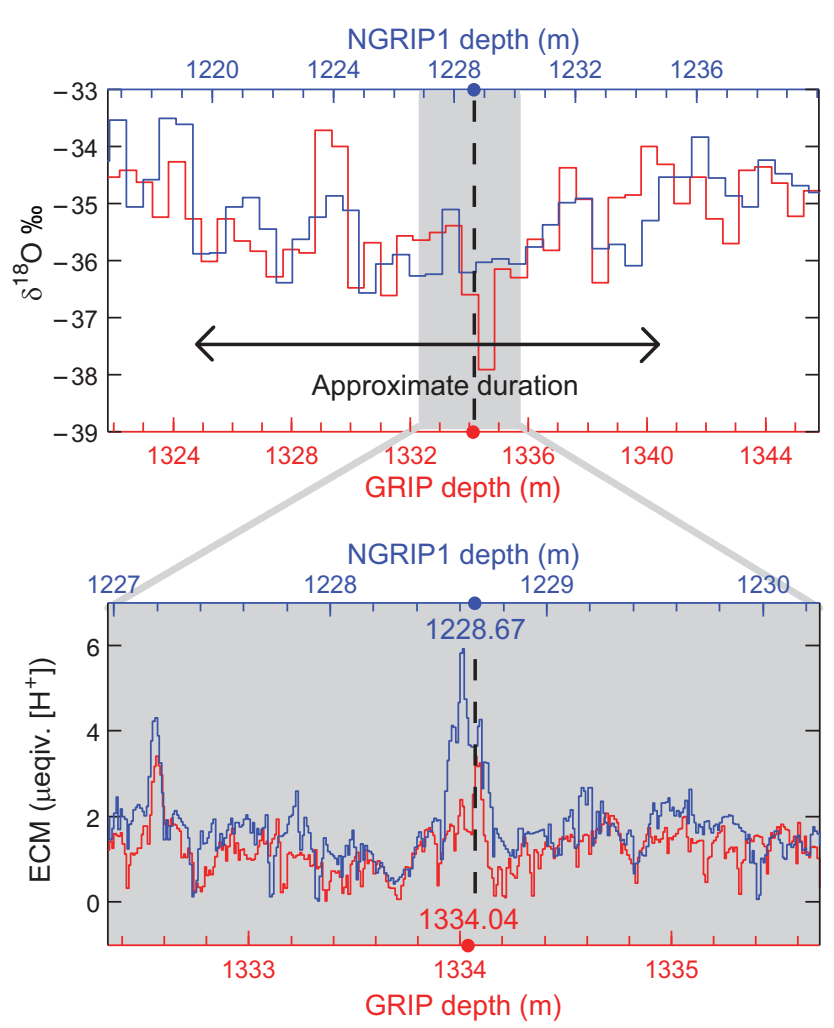

Figure 3. Top: water stable isotope ratios $\left(\delta^{18} O\right)$ at $55-\mathrm{cm}$ resolution from the GRIP and NGRIP1 ice cores around the $8.2 \mathrm{ka}$ event. The event duration depends on the criteria and dataset used, but Rasmussen et al. (2007) suggested that in NGRIP1 the event be defined from $\sim 8300$ yr b2k $(1234.78 \mathrm{~m})$ to $\sim 8140$ yr b2k $(1219.47 \mathrm{~m})$ as indicated by the black horizontal double arrow. Bottom: during the period of low $\delta^{18} O$ values (the section marked by the grey bar in the upper panel and expanded in the lower panel), a distinct acidity double peak is reflected in electrical conductivity measurements (ECM). This layer, at $1228.67 \mathrm{~m}$ depth in the NGRIPI core and $1334.04 \mathrm{~m}$ in the GRIP core (black dashed line), is characterized by a high fluoride content and can most likely be attributed to an Icelandic volcano. It is dated on the GICC05 timescale to 8236 yr b2k (8186 cal. yr BP), and is the primary marker for the Early-Middle Holocene boundary (after Walker et al., 2012).

J.-P. Steffensen) via the NGRIP Steering Committee. Hence, although the stratotype localities are in a remote region and, unlike other GSSPs, cannot be easily seen in the field, free access to the NGRIP1 and NGRIP2 cores, in which the Greenlandian and Northgrippian GSSPs are defined, can be assured at the University of Copenhagen.

\section{The Meghalayan Stage/Age; Upper/Late Holocene Sub- series/Subepoch}

The Meghalayan Stage/Age is named with with reference to the northeastern Indian State of Meghalaya in which Mawmluh Cave, which is the stratotype locality, is located (Fig. 4). The cave is on the Meghalayan Plateau, an area of conglomerates, sandstones, coal and limestones, that has been intensely karstified due to the exceptional amount of rainfall received in the region. Indeed, this is believed to be one of the wettest locations on Earth. The $7 \mathrm{~km}$ long Mawmluh Cave (entrance $25^{\circ} 15^{\prime} 44^{\prime \prime} \mathrm{N} ; 91^{\circ} 42^{\prime} 54^{\prime \prime} \mathrm{E}$ ) is at the southern edge of the plateau, is overlain by $30-100 \mathrm{~m}$ of limestone and sandstone, and formed along the contact between the Lower Eocene Lakadong dolomite (within the Sylhet Limestone Formation) and the Therria Sandstone (Breitenbach et al., 2015). The closest municipality is the town of Sohra (Cherrapunji), which is approximately $58 \mathrm{~km}$ southeast of the provincial capital, Shillong, and $15 \mathrm{~km}$ north of the border with Bangladesh.

Mawmluh Cave contains numerous speleothems (Breitenbach et al., 2015; Myers et al., 2015), the oldest published record from these being from speleothem KM-A (Fig. 5). This has provided a uraniumseries dated Upper Pleistocene to Upper Holocene stable isotope profile $\left(\delta^{18} \mathrm{O}\right.$ : Fig. 6; Berkelhammer et al., 2012), which shows a marked shift to heavier isotopic values at $\sim 4.2 \mathrm{ka}$, reflecting an abrupt reduction in precipitation due to a weakening of the monsoon across the Indian sub-continent and southeast Asia. More widely, it initiates the 4.2 ka event, a significant reorganisation of ocean and atmosphere circulation patterns (the 'Holocene Turnover': Paasche et al., 2004; Paasche and Bakke, 2009). It has also been described as the ' 4.07 ka climatic anomaly' (Railsback et al., 2018). This event is recorded in proxy records across seven continents from North America and Europe, through West Asia to China; and from Africa, Andean-Patagonian South America, Antarctica and the central North Pacific (Mayewski et al., 2004; Staubwasser and Weiss, 2006; Schimpf et al., 2011; Peck et al., 2015; Chase et al., 2017; Weiss, 2017; Bailey et al., 2018). Most mid- and low-latitude records indicate the abrupt onset of a two to three century aridification (e.g., Booth et al., 2005; Parker et al., 2006; Dixit et al., 2014b; Cheng et al., 2015; Kaniewski et al., 2017), while a few show a shift to wetter conditions (e.g., Zielhofer et al., 2017). Significant deflection or weakening of the East Asian Summer Monsoon and the Indian Summer Monsoon occurs from $4.2 \mathrm{ka}$ (Wang et al., 2005; Yang et al., 2011; Kathayat et al., 2017), while the abrupt onset of century-scale drought in Australia begins at this time with alteration of the IndoAustralian Monsoon (Quigley et al., 2010; McGowan et al., 2012). In northern high latitude regions, 'neo-glacial' conditions with marked glacier advances are pronounced at 4.2 ka (e.g., Andresen and Björck, 2005; Menounos et al., 2008; Larsen et al., 2012; Balascio et al., 2015) with glaciers, while lower Antarctica sea-surface temperatures and increased sea-ice cover start abruptly at $\sim 4.2$ ka onwards (Peck et al., 2015). In many low latitude regions, the abrupt aridification around 4.2 ka may, in some areas, have had profound societal effects, with rain-fed region abandonments, habitat-tracking to riverine refugia, and societal collapses visible archaeologically across Spain, Greece, Palestine, Egypt, Mesopotamia, the Indus Valley and the Tibetan Plateau (Stanley et al., 2003; Ponton et al., 2012; Weiss, 2014; d'Alpoim Guedes et al., 2016; Weiss, 2017; Blanco-Gonzalez et al., 2018) synchronous with the collapse of significant Neolithic societies in the regions of the Yangtze and Yellow River and North China (Liu and Feng, 2012; Guo et al., 2018). In central Africa, the first stage of Bantu expansion is coincident with the $4.2 \mathrm{ka}$ event (Maley and Vernet, 2015), while significant changes in farming practices around $4.2 \mathrm{ka}$ are evident in the American Southwest and the Yucatan (Merrill et al., 2009; Torrescano-Valle and Islebe, 2015). As with the $8.2 \mathrm{ka}$ event, therefore, the 4.2 ka event was global or near global in nature and constitutes a timestratigraphic marker horizon for defining the base of the Meghalayan Stage/Age and the Upper/Late Holocene Subseries/Subepoch. 


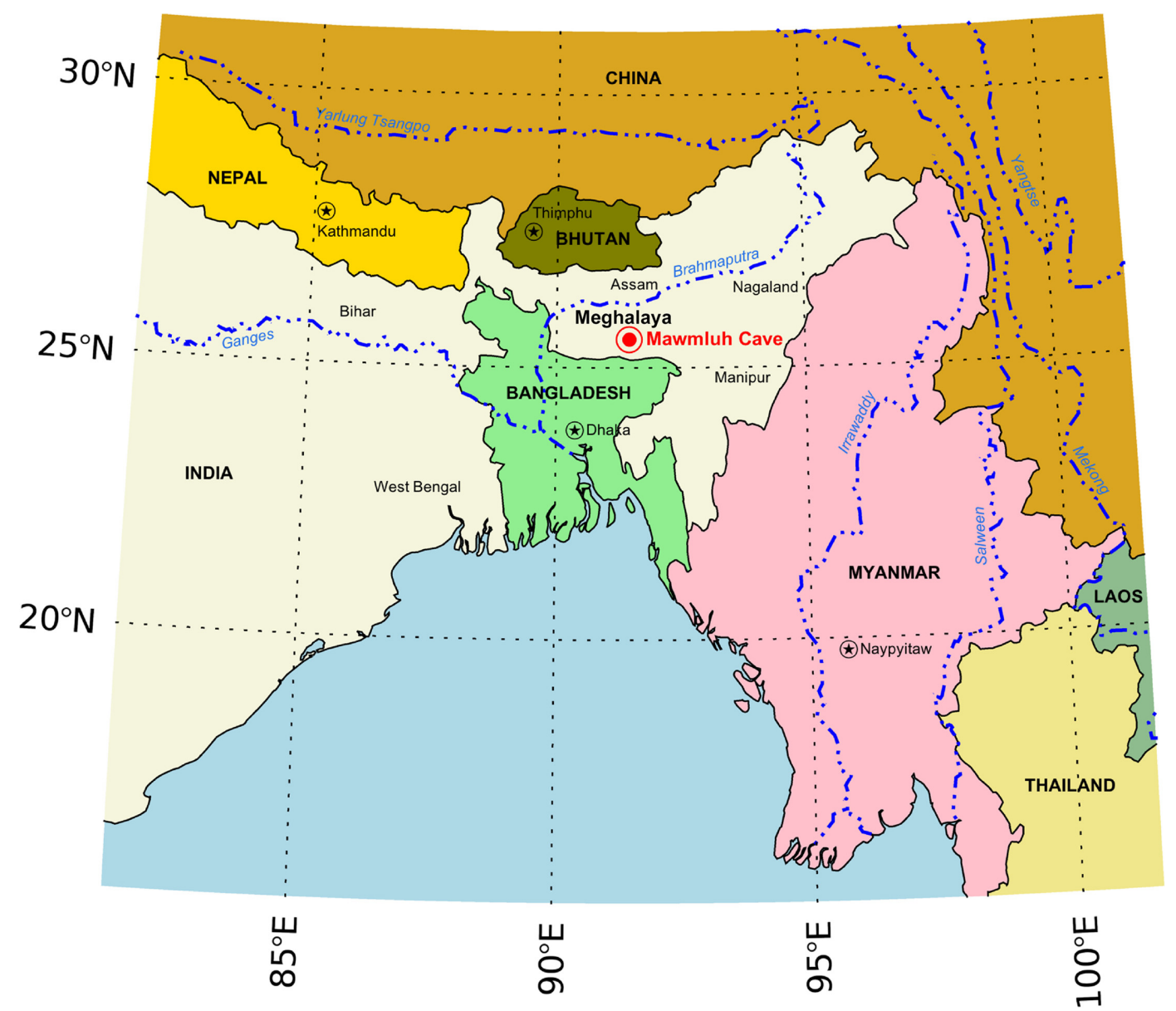

Figure 4. Location of Mawmluh Cave in northeastern India, the type locality for the Meghalayan Stage/Age and its corresponding Upper/ Late Holocene Subseries/Subepoch.
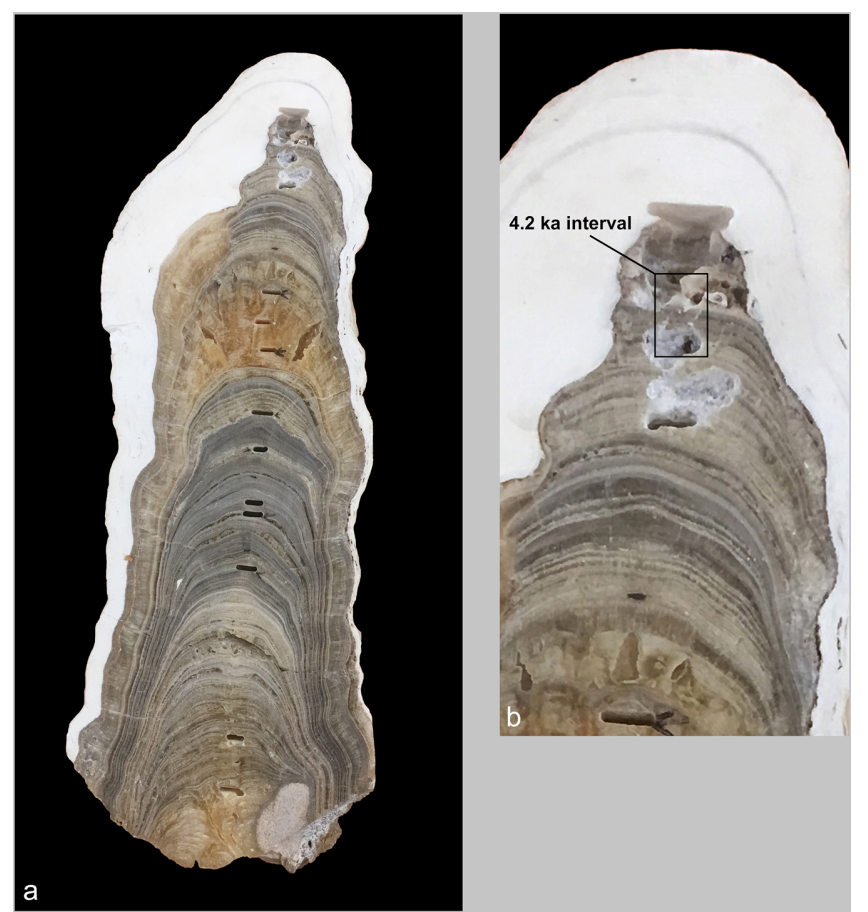

Figure 5. (a) Speleothem KM-A from Mawmluh Cave, Meghalaya, northeast India, showing (b) the position of the $4.2 \mathrm{ka}$ event. The speleothem is $\sim 308 \mathrm{~mm}$ long.
The forcing mechanisms behind the $4.2 \mathrm{ka}$ event are not well understood, but may be linked to the southward migration of the Inter-Tropical Convergence Zone (Mayewski et al., 2004) and/or cooling of North Atlantic surface waters (Bond et al., 1997), while in the Pacific, tropical 'deep' waters may also have cooled sufficiently to allow a switch-on of the modern El Niño Southern Oscillation (ENSO) regime (Gomez et al., 2004), which inhibits and weakens the Asian monsoon resulting in widespread drought conditions (Fisher et al., 2008; Fisher, 2011). As the 4.2 ka event is strongly recorded in proxy climate records from mid- and low latitudes, the stable isotope signal of the event in the Mawmluh Cave speleothem constitutes an appropriate marker horizon for the base of the Meghalayan Stage/Age and Late Holocene Subseries/ Subepoch.

The stable isotope profile from the KM-A speleothem (Fig. 6) shows a low-frequency strengthening of the monsoon from $\sim 12,000$ until $6000 \mathrm{yr}$ BP. The monsoon subsequently weakened and the stalagmite ceased to grow at $3600 \mathrm{yr}$ BP. The most notable feature of the record is a two-step increase in isotopic values beginning at $4303 \mathrm{yr} \mathrm{BP}$ and ending at $3888 \mathrm{yr}$ BP, spanning 415 years (Fig. 6). The more intense period of weakened monsoon occurred from 4071 to $3888 \mathrm{yr}$ BP, spanning an interval of 183 years (shown by the red arrows on Fig. 6). The event was characterised by an overall shift of $1.5 \%$ in $\delta^{18} \mathrm{O}$, approximately equivalent to a $20-30 \%$ decrease in monsoon rainfall. The unique characteristics of this record are a combination of good age control 


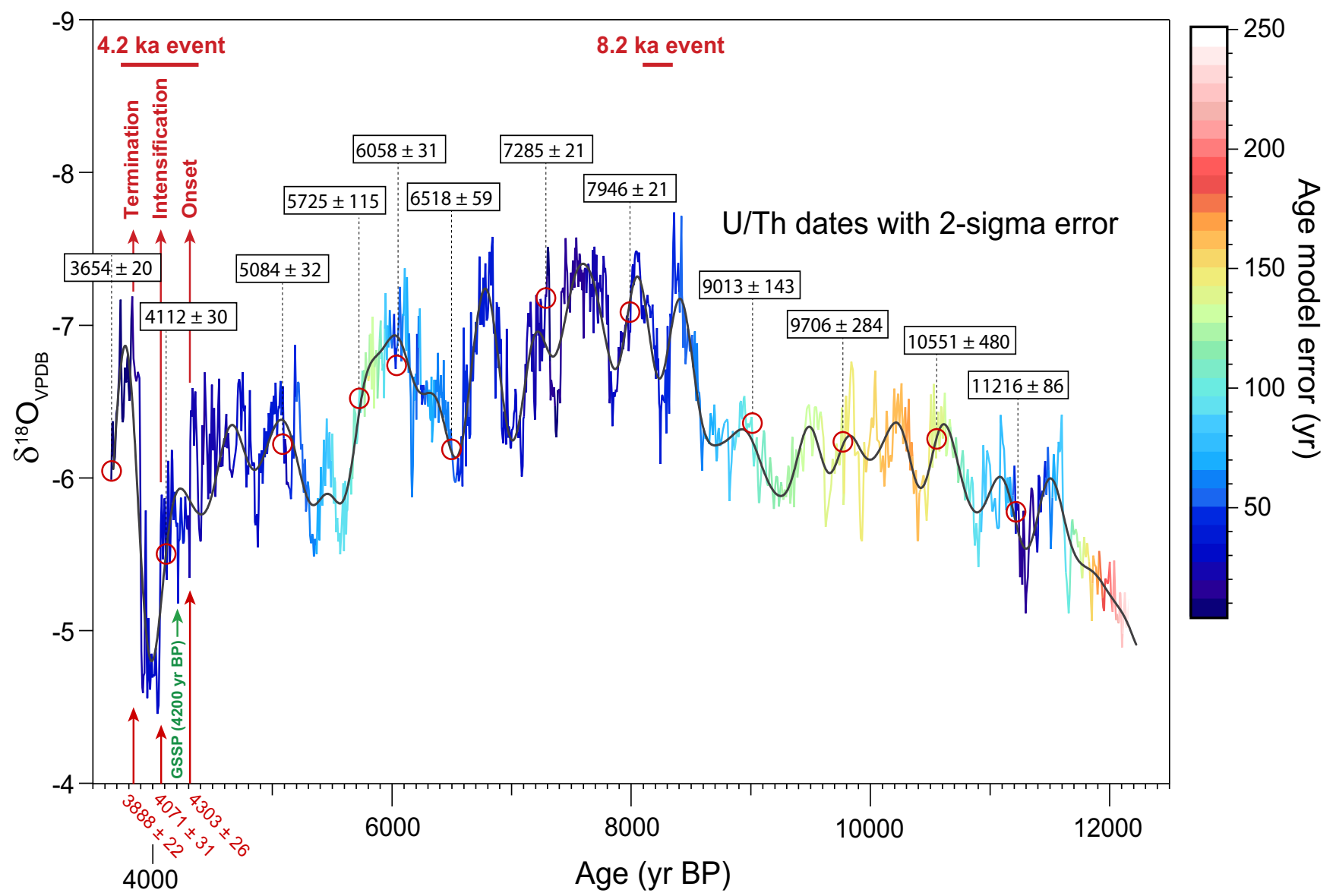

Figure 6. The Mawmluh Cave $\delta^{18}$ O record for speleothem KM-A, showing the position of the 4.2 ka event on the stable isotope trace (after Berkelhammer et al., 2012). The continuous black line through the isotope trace is a low pass filter removing any variability with a frequency higher than 10 years. Red circles mark all $U$-Th dates obtained, which are given with their $2 \sigma$ analytical uncertainty in black boxes. Age uncertainty (95\% confidence interval) was assessed using a Monte Carlo fitting procedure through the U-Th dates, and is also shown by variations in colour along the trace. The envelope of the event (onset and termination) is shown by the arrowed red lines, and the beginning of the most intensive phase of weakened monsoon is shown by a third arrowed red line: their dates (in red) are given with uncertainty that is also assessed using the Monte Carlo fitting procedure. See Berkelhammer et al. (2012) for details on the age model calculations. The position of the GSSP, with a modelled age of $4200 \mathrm{yr} \mathrm{BP}(4250 \mathrm{~b} 2 \mathrm{k})$ is indicated by the green arrow. Note that the $8.2 \mathrm{ka}$ event also registers as a significant excursion in the stable isotope record from Mawmluh Cave.

derived through U-Th dating of the stalagmite (see below), and a sample resolution of around, or less than, 5 years.

An age model for the stable isotope record for speleothem KM-A was developed using a Monte Carlo fitting procedure through $12 \mathrm{U}-\mathrm{Th}$ dates (Scholz and Hoffman, 2011). The analytical uncertainty on the two U-Th dates closest to the 4.2 ka event (3654 and $4112 \mathrm{yr}$ BP) are 20 and 30 years respectively, with a third date at $5084 \mathrm{yr}$ BP having an uncertainty of \pm 32 years. The KM-A record shows linear growth rates during this period which provides further confidence in the timing (onset and duration) of the 4.2 ka event (Berkelhammer et al., 2012). The first registration of the event in the stable isotope record occurs at $\sim 4300$ yr BP followed by a second marked increase in stable isotope values at $\sim 4100 \mathrm{yr}$ BP. The abrupt increase in stable isotope values is the primary boundary marker for the GSSP, and hence a date of 4200 yr BP, which effectively marks the mid-point between these two modelled ages, can be assigned (Fig. 6). The age estimates are well within the range of ages for climatic proxies from other records for the $4.2 \mathrm{ka}$ event described above. Here, the U-Th ages are expressed relative to a baseline date of $1950 \mathrm{CE}$ and are therefore directly comparable with the calibrated radiocarbon time scale. However, in order to maintain consistency with the earlier Holocene GSSPs (the Greenlandian and Northgrippian) which are dated using the GICC05 ice-core chronology relative to the b2k datum, we quote the age of the Mawmluh speleothem GSSP as $4250 \mathrm{yr}$ b2k (before $2000 \mathrm{CE}$ : see above). Accordingly, the GSSP for the Meghalayan Stage/Age and corresponding Upper/ Late Holocene Subseries/Subepoch is defined in the Mawmluh Cave speleothem from northeast India, with a modelled age of $4250 \mathrm{yr}$ b2k.

Access to Mawmluh Cave in Meghalaya, northeast India, can be arranged through the National Cave Research and Protection Organization (http://caves.res.in), which is registered under the Government of India Societies Registration Act of 1860 . This is currently headed by Dr Jayant Biswas, at the Central Office, 3/40 Civil Lines, Rajalab, Raipur, 492001C.G., India. The speleothem KM-A, in which the GSSP for the Meghalayan Stage/Age and the coincident Late/Upper Holocene Subseries/Subepoch are recorded, will be conserved at the Birbal Sahni Institute of Palaeosciences, Lucknow, Uttar Pradesh, India. 


\section{Summary and Conclusions}

Whereas most current GSSPs use biostratigraphic data as primary markers, it has been recommended that future GSSPs should have physico-chemical markers as an integral part of their guiding criteria (Smith et al., 2014; Miller and Wright, 2017). Indeed, as Head and Gibbard (2015) have noted, the International Stratigraphic Guide (Hedberg, 1976, p. 82; Salvador, 1994, p. 88) allows certain methods of correlation, such as climatic, palaeomagnetic, and isotopic, to have greater emphasis for Quaternary chronostratigraphy. The subdivision of the Holocene as outlined above is therefore entirely in keeping with that recommendation, as all three of the GSSPs are defined on the basis of physical and chemical markers. These reflect abrupt climatic events at the onset of the Holocene ( $\sim 11.7 \mathrm{ka}$ ), at $\sim 8.2 \mathrm{ka}$ and $\sim 4.2 \mathrm{ka}$, all of which are global or near global in their expression. Stable isotope records in particular, from both Holocene ice-core and speleothem successions, have proved to be remarkably sensitive proxies for climate change, and can be dated with a very high degree of accuracy and precision. Indeed, the designated GSSPs described here may be the best-resolved, both stratigraphically and temporally, within the entire geological time scale. They closely accord with the criteria for boundary stratotypes outlined in Remane et al. (1996), and should provide stable points of reference for Holocene stages/ages and subseries/subepochs into the future.

Ratification of the Holocene GSSP in 2008 established the precedent of using an ice core to define a GSSP, and this has now been followed with the Northgrippian Stage GSSP. However, ratification of the Meghalayan Stage GSSP in a speleothem sets a new precedent and not only facilitates unusually high dating precision but allows a GSSP to be displayed for the first time in a museum. Ratification of the Lower/Early, Middle, and Upper/Late Holocene (corresponding precisely to the Greenlandian, Northgrippian and Meghalayan stages/ ages) now formalises the rank of subseries/subepoch for the Holocene. This finally resolves the editorial dilemma of whether to capitalise the initial letter of the positional term (Head et al., 2017) for this time interval.

\section{Acknowledgements}

We would like to thank all those members of the Subcommission on Quaternary Stratigraphy (SQS) and of the International Commission on Stratigaphy (ICS) for their comments on the original proposal. We are particularly grateful to Professors Stan Finney, Philip Gibbard and David Harper for their support throughout the review process, to Dr Ashish Sinha for his assistance with the KM-A speleothem and for providing Figure 5, and to Cynthia Garcia-Eidell for her production of Figure 4.

\section{References}

Alley, R.B., and Ágústsdottir, A.M., 2005, The 8k event: cause and consequences of a major Holocene abrupt climate change. Quaternary Science Reviews, v. 24, pp. 1123-1149.

Andersen, K.K., Svensson, A., Rasmussen, S.O., Steffensen, J.-P., Johnsen, S.J., Bigler, M., Röthlisberger, R., Ruth, U., Siggard-Andersen, M.-L.,
Dahl-Jensen, D., Vinther, B.M., and Clausen, H.B., 2006, The Greenland Ice Core Chronology 2005, 15-42 ka. Part 1. Constructing the time scale. Quaternary Science Reviews, v. 25, pp. 3246-3257.

Andresen, C., and Björck, S., 2005, Holocene climate variability in the Denmark Strait region - a land-sea correlation of new and existing climate proxy records. Geografiska Annaler, v. 87A, pp. 159-174.

Augustinus, P., Bleakley, N., Deng, Y., Shane, P., and Cochran, U., 2008, Rapid change in early Holocene environments inferred from Lake Pupuke, Auckland City, New Zealand. Journal of Quaternary Science, v. 23, pp. 435-447.

Bailey, H.L., Kaufman, D.S., Sloane, H.J., Hubbard, A.L., Henderson, A.C.G., Leng, M., Meyer, H., and Welker, J.M., 2018, Holocene atmospheric circulation in the central North Pacific: a new terrestrial diatom and $\delta^{18} \mathrm{O}$ dataset from the Aleutian Islands. Quaternary Science Reviews, v. 194, pp. 27-38.

Balascio, N.L., D'Andrea, W.J., and Bradley, R.S., 2015, Glacier response to North Atlantic climate variability during the Holocene. Climate of the Past, v. 11, pp. 1587-1598.

Berkelhammer, M.B., Sinha, A., Stott, L., Cheng, H., Pausata, F.S.R., and Yoshimura, K., 2012, An abrupt shift in the Indian Monsoon 4000 years ago. Geophysical Monographs Series, v. 198, pp. 75-87.

Björck, S., Walker, M.J.C., Cwynar, L.C., Johnson, S.J., Knudsen, K.-L., Lowe, J.J., Wohlfarth, B., and INTIMATE Members, 1998, An event stratigraphy for the Last Termination in the North Atlantic region based on the Greenland ice-core record: a proposal by the INTIMATE group. Journal of Quaternary Science, v. 13, pp. 283-292.

Blanco-Gonzalez, A., Lillios K.T., Lopez-Saez, J.A., and Drake, B.L., 2018, Demographic and environmental dynamics of the Copper and Early Bronze Age in Iberia (3300-1500 BC): towards an interregional multiproxy comparison at the time of the $4.2 \mathrm{ky}$ BP event. Journal of World Prehistory. https://doi.org/10.1007/s10963-018-9113-3

Bond, G., Showers, W., Cheseby, M., Lotti, R., Almasi, P., de Menocal, P., Priore, P., Cullen, H., Hajdas, I., and Bonani, G., 1997, A pervasive millennial scale cycle in North Atlantic Holocene and Glacial climates. Science, v. 278, pp. 1257-1266.

Booth, R.K., Jackson, S.T., Forman, S.L., Kutzbach, J.E., Bettis, E.A. III, Kriegs, J., and Wright, D.K., 2005, A severe centennial-scale drought in mid-continental North America 4200 years ago and apparent global linkages. The Holocene, v. 15, pp. 321-328.

Breitenbach, S.F.M., Lechleitner, F.A., Meyer, H., and Diengdoh, G., 2015, Cave ventilation and rainfall signals in dripwater in a monsoonal setting - a monitoring study from NE India. Chemical Geology, v. 402, pp. 111-124.

Chase, B.M., Chevalier, M., Boom, A., and Carr, A.S., 2017, The dynamic relationship between temperate and tropical circulation systems across South Africa since the last glacial maximum. Quaternary Science Reviews, v. 174, pp. 54-62.

Chen, T., Wang Z., Wu X., Gao, X., Li, L., and Zhan, Q., 2015, Magnetic properties of tidal flat sediments on the Yangtse coast, China: early diagenetic alteration and implications. The Holocene, v. 25, pp. 832-843.

Cheng, H., Fleitmann, D., Edwards, R.L, Wang, X., Cruz, F.W., Auler, A.S., Mangini, A., Wang, Y., Kong, X., Burns, S.J., and Matter, A., 2009, Timing and structure of the $8.2 \mathrm{kyr}$ B.P. event inferred from $\delta^{18} \mathrm{O}$ records of stalagmites from China, Oman and Brazil. Geology, v. 37, pp. 10071010.

Cheng, H., Sinha, A., Verheyden, S., Nader, F.H., Li, X.L., Zhang, P.Z., Yin, J.J., Yi, L., Peng, Y.B., Rao, Z.G., Ning, Y.F., and Edwards, R.L., 2015, The climate variability in northern Levant over the past 20,000 years. Geophysical Research Letters, v. 42, pp. 8641-8650.

Cita, M.B., Capraro, L., Ciaranfi, N., Di Stefano, P., Marino, M., Rio, D., Sprovieri, R., and Vai, G.B., 2006, Calabrian and Ionian: a proposal for the definition of Mediterranean stages for the Lower and Middle Pleistocene. Episodes, v. 29, pp. 107-114.

Cita, M.B., Capraro, L., Ciaranfi, N., Di Stefano, E., Maiorano, P., Marino, M., Raffi, I., Rio, D., Sprovieri, R., Steffanelli, S.A., and Vai, G.B., 
2008, The Calabrian Stage refined. Episodes, v. 31, pp. 418-429.

Cita, M.B., Gibbard, P.L., Head, M.J., and the ICS Subcommission on Quaternary Stratigraphy, 2012, Formal ratification of the GSSP for the base of the Calabrian Stage (second stage of the Pleistocene Series, Quaternary System). Episodes, v. 35, pp. 388-397.

Cohen, K.M., and Hijma, M.P., 2014, The transgressive Early-Middle Holocene boundary: The case for a GSSP at Rotterdam, Rhine Delta, North Sea. In: Rocha, R.B., Pais, J., Kullberg, J.C., and Finney, S. (Eds.), STRATI 2013. Springer Geology, Switzerland, pp. 925-929. https://doi.org/10.1007/978-3-319-04364-7_174

Cremer, H., Heiri, O., Wagner, B., and Wagner-Cremer, F., 2007, Abrupt climatic warming in East Antarctica during the early Holocene. Quaternary Science Reviews, v. 26, pp. 2012-2018.

D’Alpoim Guedes, J., Manning, S.W., and Bocinsky, R.K., 2016, A 5,500year model of changing crop niches on the Tibetan Plateau. Current Anthropology, v. 57, pp. 517-522.

Dixit, Y., Hodell, D.A., and Sinha, R., 2014a, Abrupt weakening of the Indian summer monsoon at $8.2 \mathrm{kyr}$ BP. Earth and Planetary Science Letters, v. 39, pp. 16-23.

Dixit, Y., Hodell, D.A., and Petrie, C., 2014b, Abrupt weakening of the summer monsoon in northwest India $\sim 4100$ yr ago. Geology, v. 42, pp. 339-342.

Fisher, D.A., 2011, Connecting the Atlantic-sector and the north Pacific (Mt Logan) ice core stable isotope records during the Holocene: the role of El Niño. The Holocene, v. 21, pp. 1117-1124.

Fisher, D., Osterberg, E., Dyke, A., and Ruyper, S., 2008, The Mt Logan Holocene-late Wisconsinan isotope record: tropical Pacific-Yukon connection. The Holocene, v. 18, pp. 1-11.

Forbes, E., 1846, On the connexion between the distribution of the existing fauna and flora of the British Isles, and the geological changes which have affected their area, especially during the epoch of the Northern Drift. Memoirs of the Geological Survey of Great Britain and of the Museum of Economic Geology in London, Longman, Brown, Green, and Longmans, London, v. 1, pp. 336-432.

Gasse, F., 2000, Hydrological changes in the African tropics since the Last Glacial Maximum. Quaternary Science Reviews, v. 19, pp. 189-211.

Gervais, P., 1867-69, Zoologie et Paléontologie Générales: Nouvelles Recherches sur les Animaux Vértetebrés Vivants et Fossiles (two volumes). Bertrand, Paris, 263 p. +50 pls.

Gibbard, P.L., and Head, M.J., 2009, The definition of the Quaternary System/Period and the Pleistocene Series/Epoch. Quaternaire v. 20, pp. 125-133.

Gibbard, P.L., and Head, M.J., 2010, The newly-ratified definition of the Quaternary System/Period and redefinition of the Pleistocene Series/ Epoch, and comparison of proposals advanced prior to formal ratification. Episodes, v. 33, pp. 152-158.

Gibbard, P.L., Head, M.J., Walker, M.J.C., and the Subcommission on Quaternary Stratigraphy, 2010, Formal ratification of the Quaternary System/Period and the Pleistocene Series/Epoch with a base at 2.58 Ma. Journal of Quaternary Science, v. 25, pp. 96-102.

Gkinis, V., Simonsen, S.B., Buchardt, S.L, White, J.W., and Vinther, B.M., 2014, Water isotope diffusion rates from the NorthGRIP ice core for the last 16,000 years - glaciological and palaeoclimatic implications. Earth and Planetary Science Letters, v. 405, pp. 132-141.

Gomez, B., Carter, L., Trustrum, N.A., Palmer, A.S., and Roberts, A.P., 2004, El Niño-Southern Oscillation signal associated with middle Holocene climatic change in intercorrelated terrestrial and marine sediment cores, New Zealand. Geology, v. 32, pp. 653-656.

Guo, L., Xiong, S., Ding, Z., Wu, J., and Ye, W., 2018, Role of mid-Holocene environmental transition in the decline of late Neolithic cultures in the deserts of NE China. Quaternary Science Reviews, v. 190, pp. 98-113.

Head, M.J., and Gibbard, P.L., 2015, Formal subdivision of the Quaternary System/Period: past, present and future. Quaternary International, v. 383, pp. 4-35.
Head, M.J, Pillans, B., and Farquhar, S., 2008, The Early-Middle Pleistocene Transition: characterisation and proposed guide for defining the boundary. Episodes, v. 31, pp. 255-259.

Head, M.J., Aubry, M.-P., Walker, M., Miller, K.G., and Pratt, B.R., 2017, A case for formalizing subseries (subepochs) in the Cenozoic Era. Episodes, v. 40, pp. 22-27.

Hedberg, H.D. (Ed.), 1976, International Stratigraphic Guide. John Wiley and Sons, New York, $200 \mathrm{p}$.

Hoffman, J.S., Carlson, A.E., Winsor, K., Klinkhammer, G.P., LeGrande, A.N., Andrews, J.T., and Strasser, J.C., 2012, Linking the 8.2 ka event and its freshwater forcing in the Labrador Sea. Geophysical Research Letters, v. 39, L18703. https://doi.org/10.1029/2012/GL053047

Holmes, J.A., Tindall, J., Roberts, N., Marshall, W., Marshall, J.D., Bingham, A., Feeser, I., O'Connell, M., Atkinson, T., Jourdan, A.-L., March, A., and Fisher, E.H., 2016, Lake isotope records of the 8200-year cooling event in western Ireland: comparison with model simulations. Quaternary Science Reviews, v. 131, pp. 341-349.

Hua, Y., Yingqian, X., Zhenxia, L., and Guodong, J., 2008, Evidence for the 8,200 a BP cooling event in the middle Okinawa Trough. Geo-Marine Letters, v. 28, pp. 131-136.

Kaniewski, D., Marriner, N., Ilan, D., Morhange, C., Threani, Y., and Van Campo, E., 2017, Climate change and water management in the biblical city of Dan. Science Advances, v. 3. https://doi.org/10.1126/sciadv.1700954

Kathayat, G., Cheng, H., Sinha, A., Yi, L., Li, X., Zhang, H., Li, H., Ning, Y., and Edwards, R.L., 2017, The Indian monsoon variability and civilisation changes in the Indian subcontinent. Science Advances, v. 3. https://doi.org/10.1126/sciadv.1701296

Kleiven, H.F., Kissel, C., Laj, C., Ninnemann, U.S., Richter, T.O., and Corrijo, E., 2008, Reduced North Atlantic Deep Water coeval with the Glacial Lake Agassiz freshwater outburst. Science, v. 319, pp. 60-64

Larsen, D.J., Miller, G.H., Geirsdóttir, Á., and Ólafsdóttir, S., 2012, Nonlinear Holocene climate evolution in the North Atlantic: a high-resolution, multiproxy record of glacier activity and environmental change from Hvítárvatn, central Iceland. Quaternary Science Reviews, v. 39, pp. 125-145.

Liu, F., and Feng, Z., 2012, A dramatic climatic transition at 4000 cal. yr $\mathrm{BP}$ and its cultural responses in Chinese cultural domains. The Holocene, v. 22, pp. 1181-1197.

Lyell, C., 1839, Nouveaux Éléments de Géologie. Pitois-Levrault et Cie, Paris, $648 \mathrm{p}$.

Maley, J., and Vernet, R., 2015, Populations and climatic evolution in North Tropical Africa from the end of the Neolithic to the dawn of the Modern Era. African Archaeological Review, v. 32, pp. 179-232.

Mangerud, J., Andersen, S.T., Berglund, B.E., and Donner, J.J., 1974, Quaternary stratigraphy of Norden, a proposal for terminology and classification. Boreas, v. 3, pp. 109-126.

Masson-Delmotte, V., Landais, A., Stievenard, M., Cattani, O., Falourd, S., Jouzel, J., Johnson, S.J., Dahl-Jensen, D., Sveinsbjornsdottir, A., White, J.W.C., Popp, T., and Fischer, H., 2005, Holocene climatic changes in Greenland: different deuterium excess signals at Greenland Ice Core Project (GRIP) and NorthGRIP. Journal of Geophysical Research, v. 110, D14102. https://doi.org/10.1029/2004JD005575

Matero, I.S.O., Gregoire, L.J., Ivanovic, R.F., Tindall, J.C., and Haywood, A.M., 2017, The 8.2 ka cooling event caused by Laurentide ice saddle collapse. Earth and Planetary Science Letters, v. 73, pp. 205-214.

Mayewski, P.A., Rohling, E.E., Stager, J.C., Karlén, W., Maasch, K.A., Meeker, L.D., Meyerson, E.A., Gasse, F., van Kreveld, S., Holmgren, K., Lee-Thorp, J., Rosqvist, G., Rack, F., Staubwasser, M., Schneider, R.R., and Steig, E., 2004, Holocene climate variability. Quaternary Research, v. 62, pp. 243-255.

McGowan, H., Marx, S., Moss, P., and Hammond, A., 2012, Evidence of ENSO mega-drought triggered collapse of prehistory Aboriginal society in northwest Australia. Geophysical Research Letters, v. 39, L22702. https://doi.org/10.10129/2012GL053916

Meese, D.A., Gow, A.J., Alley, R.B., Zielinski, G.A., Grootes, P.M., Ram, 
M., Taylor, K.C., Mayewski, P.A., and Bolzan, J.F., 1997, The Greenland Ice Sheet Project 2 depth-age scale: methods and results. Journal of Geophysical Research, v. 102, pp. 26411-26423.

Menounos, B., Clague, J.J., Osborn, G., Luckman, B.H., Lakeman, T.R., and Minkus, R., 2008, Western Canadian glaciers advance in concert with climate change circa $4.2 \mathrm{ka}$. Geophysical Research Letters, v. 35, L07501. https://doi.org/10.1029/2008GL033172

Merrill, W.L., Hard, R.J., Mabry, J.B., Fritz, G.J., Adams, K.R., Roney, J.R., and MacWilliams, A.C., 2009, The diffusion of maize to the southwestern United States and its impact. Proceedings of the National Academy of Sciences, v. 106, pp. 21019-21026.

Miller, K.G., and Wright, J.D., 2017, Success and failure in Cenozoic global correlations using golden spikes: a geochemical and magnetostratigraphic perspective. Episodes, v. 40, pp. 8-21.

Myers, C.G., Oster, J.L., Sharp, W., Bennartz, R., Kelley, N.P., Covey, A.K., and Breitenbach, S.F.M., 2015, Northeast Indian stalagmite records Pacific decadal climate change: implications for moisture transport and drought in India. Geophysical Research Letters, v. 42, pp. 4124-4132.

Oster, J.L., Sharp, W.D., Covey, A.K., Gibson, J., Rogers, B., and Mix, H., 2017 , Climate response to the $8.2 \mathrm{ka}$ event in coastal California. Scientific Reports, v. 7, 3886. https://doi.org/10.1038/s41598-017-04215-5

Paasche, Ø., and Bakke, J., 2009, The Holocene Turnover - a global climate shift at $4 \mathrm{ka}$. Proceedings of the EGU General Assembly 2009 (Geophysical Research Abstracts), Vienna, Apr. 19-24, v. 11, EGU2009-14017.

Paasche, Ø., Løvlie, R., Dahl, S.O., Bakke, J., and Nesje, A., 2004, Bacterial magnetite in lake sediments: late glacial to Holocene climate and sedimentary changes in northern Norway. Earth and Planetary Science Letters, v. 223, pp. 319-333.

Parker, A.G., Goudie, A.S., Stokes S., and Kennett, D., 2006, A record of Holocene climate change from lake geochemical analyses in southeastern Arabia. Quaternary Research, v. 66, pp. 465-476.

Peck, V.L., Allen, C.S., Kender, S., McClymont, E.L., and Hodgson, D.A., 2015, Oceanographic variability on the West Antarctic Peninsula during the Holocene and the influence of upper circumpolar deep water. Quaternary Science Reviews, v. 119, pp. 54-65.

Peyron, O., Goring, S., Dormoy, I., Kotthoff, U., Pross, J., de Beaulieu, J.L., Drescher-Schneider, R., Vannière, B., and Magny, M., 2011, Holocene seasonality changes in the central Mediterranean region reconstructed from the pollen sequences of Lake Accessa (Italy) and Tenaghi Philippon (Greece). The Holocene, v. 21, pp. 131-146.

Ponton, C., Giosan, L., Eglinton, T.I., Fuller, D.Q., Johnson, J.E., Kumar, P., and Collett, T.S., 2012, Holocene aridification of India. Geophysical Research Letters, v. 39. https://doi.org/10.1029/2011GL050722

Pross, J., Kotthoff, U., Müller, U.C., Peyron, O., Dormoy, I., Schmiedl, G., Kalaitzidis, S., and Smith, A.M., 2009, Massive perturbation in terrestrial ecosystems of the Eastern Mediterranean region associated with the 8.2 kyr B.P. climatic event. Geology, v. 37, pp. 887-890.

Quigley, M.C., Horton, T., Hellstrom, J.C., Cupper, M.L., and Sandford, M., 2010, Holocene climate change in arid Australia from speleothem and alluvial records. The Holocene, v. 20, pp. 1093-1104.

Railsback, L.B., Liang, F., Brook, G.A., Voarintsoa, N.G., Sletten, H.R., Maraia, E., Hardt, B., Cheng, H., and Edwards, R.L., 2018, The timing, two-pulsed nature, and variable climatic expression of the $4.2 \mathrm{ka}$ event: a review and high-resolution stalagmite data from Namibia. Quaternary Science Reviews, v. 186, pp. 78-90.

Rasmussen, S.O., Andersen, K.K., Svensson, A.M., Steffensen, J.P., Vinther, B.M., Clausen, H.B., Siggard-Andersen, M.L., Johnsen, S.J., Larsen, L.B., Bigler, M., Röthlisberger, R., Fischer, H., Goto-Azuma, K., Hansson, M.E., and Ruth, U., 2006, A new Greenland ice core chronology for the last glacial termination. Journal of Geophysical Research, v. 111, D06102. https://doi.org/10.1029/ 2005JD 006079

Rasmussen, S.O., Vinther, B.M., Clausen, H.B., and Andersen, K.K., 2007, Early Holocene climate oscillations recorded in three Greenland ice cores. Quaternary Science Reviews, v. 26, pp. 1907-1914.

Remane, J., Bassett, M.G., Cowie, J.W., Gohrbandt, K.H., Lane, H.R.,
Michelsen, O., and Wang, N., 1996, Revised guidelines for the establishment of global chronostratigraphic standards by the International Commission on Stratigraphy (ICS). Episodes, v. 19, pp. 77-81.

Rohling, E., and Pälike, H., 2005, Centennial-scale climate cooling with a sudden cold event around 8,200 years ago. Nature, v. 434, pp. 975-979.

Salvador, A. (Ed.), 1994, International Stratigraphic Guide: A Guide to Stratigraphical Classification, Terminology and Procedure ( $2^{\text {nd }}$ edition$)$. International Commission on Stratigraphic Classification of IUGS, International Commission on Stratigraphy and the Geological Society of America, Boulder, Colorado, $214 \mathrm{p}$.

Schimpf, D., Kilian, R., Kronz, A., Klaus, S., Spötl, C., Wörner, G., Deininger, M., and Mangini, A., 2011, The significance of chemical, isotopic and detrital components in three coeval stalagmites from the superhumid southernmost Andes $\left(53^{\circ} \mathrm{S}\right)$ as high-resolution paleo-climate proxies. Quaternary Science Reviews, v. 30, pp. 443-459.

Scholz, D., and Hoffman, D.L., 2011, StalAge - An algorithm designed for construction of speleothem age models. Quaternary Geochronology, v. 6, pp. 369-382.

Smith, A.G., Barry, T.L., Bown, P., Cope, J.W.C., Gale, A., Gibbard, P.L., Gregory, F.J., Hounslow, M.W., Kemp, D.B., Knox, R.W., Marshall, J.E.A., Oates, M., Rawson, P., Powell, J.H., and Waters, C.N., 2014, GSSPs, global stratigraphy and correlation. In: Smith, D.G., Bailey, R.J., Burgess, P.M., and Fraser, A.J. (Eds.), Strata and Time: Probing the Gaps in our Understanding. The Geological Society, London, Special Publications, v. 404, pp. 37-67.

Snowball, I., Muscheler, R., Zillén, L., Sandgren, P., Stanton, T., and Ljung, K., 2010, Radiocarbon wiggle matching of Swedish lake varves reveals synchronous climatic changes around the $8.2 \mathrm{kyr}$ cold event. Boreas, v. 39, pp. 720-733.

Stanley, J.-D., Krom, M.D., Cliff, R.A., and Woodward, J.C., 2003, Nile flow failure at the end of the Old Kingdom, Egypt: strontium isotope and petrologic evidence. Geoarchaeology, v. 18, pp. 395-402.

Staubwasser, M., and Weiss, H., 2006, Holocene climate and cultural evolution in late prehistoric-early historic West Asia. Quaternary Research, v. 66, pp. 372-387.

Steffensen, J.P., Andersen, K.K., Bigler, M., Clausen, H.B., Dahl-Jensen, D., Fischer, H., Goto-Azuma, K., Hansson, M., Johnsen, S.J., Jouzel, J., Masson-Delmotte, V., Popp, T., Rasmussen, S.O., Röthlisberger, R., Ruth, U., Stauffer, B., Siggard-Andersen, M.-L., Sveinsbjörnsdóttir, Á.E., Svensson, A., and White, J.W.C., 2008, High-resolution Greenland ice core data show abrupt climate change happens in a few years. Science, v. 321, pp. 680-684.

Thompson, L.G., Mosley-Thompson, E., Davis, M.E., David, M.E., Henderson, K.A., Brecher, H.H., Zagorodnov, V.S., Mashiotta, T.A., Lin, P.-N., Mikhalenko, V.N., Hardy, D.R., and Beer, J., 2002, Kilimanjaro ice core records: evidence of Holocene climate change in Tropical Africa. Science, v. 298, pp. 589-593.

Torrescano-Valle, N., and Islebe, G.A., 2015, Holocene paleoecology, climate history and human influence in the southwestern Yucatan Peninsula. Review of Palaeobotany and Palynology, v. 217, pp. 1-8.

Velichko, A.A., Andreev, A.A., and Klimanov, V.A., 1997, Climate and vegetation dynamics in the tundra and forest zone during the Late Glacial and Holocene. Quaternary International, v. 41/42, pp. 71-96.

Vinther, B., Clausen, H.B., Johnsen, S.J., Rasmussen, S.O., Andersen, K.K., Buchardt, S.L., Dahl-Jensen, D., Seierstad, I.K., Siggard-Andersen, M.-L., Steffensen, J.P., Svensson, A., Olsen, J., and Heinemeier, J., 2006, A synchronised dating of three Greenland ice cores throughout the Holocene. Journal of Geophysical Research, v. 111, D13102. https:/ /doi.org/10.1029/2005JD006921

Vossel, H., Roeser, P., Litt, T., and Reed, J.M., 2018, Late Kinneret (Israel): new insights into Holocene regional palaeoclimate variability based on high-resolution multi-proxy analysis. The Holocene. https://doi.org/ 10.1177/0959683618777071

Walker, M., Johnsen, S., Rasmussen, S.O., Steffensen, J.P., Popp, T., Gibbard, P., Hoek, W., Lowe, J., Björck, S., Cwynar, L.C., Hughen, K., Ker- 
shaw, P., Kromer, B., Litt., T., Lowe, D.J., Nakagawa, T., Newnham, R., and Schwander, J., 2008, The Global Stratotype Section and Point (GSSP) for the base of the Holocene Series/Epoch (Quaternary System/Period) in the NGRIP ice core. Episodes, v. 31, pp. 264-267.

Walker, M., Johnsen, S., Rasmussen, S.O., Steffensen, J.P., Popp, T., Gibbard, P., Hoek, W., Lowe, J., Andrews, J., Björck, S., Cwynar, L.C., Hughen, K., Kershaw, P., Kromer, B., Litt, T., Lowe, D.J., Nakagawa, T., Newnham, R., and Schwander, J., 2009, Formal definition and dating of the GSSP (Global Stratotype Section and Point) for the base of the Holocene using the Greenland NGRIP ice core, and selected auxiliary records. Journal of Quaternary Science, v. 24, pp. 3-17.

Walker, M.J.C., Berkelhammer, M., Björck, S., Cwynar, L.C., Fisher, D.A., Long, A.J., Lowe, J.J., Newnham, R.M., Rasmussen, S.O., and Weiss, H., 2012, Formal subdivision of the Holocene Series/Epoch: a discussion paper by a working group of INTIMATE (Integration of icecore, marine and terrestrial records) and the Subcommission on Quaternary Stratigraphy (International Commission on Stratigraphy). Journal of Quaternary Science, v. 27, pp. 649-659.

Wang, Y., Cheng, H., Edwards, R.L., He, Y., Kong, X., An, Z., Wu, J., Kelly, M.J., Dykoski, C.A., and Li, X., 2005, The Holocene Asian monsoon: links to solar changes and North Atlantic climate. Science, $\mathrm{v}$. 308, pp. 854-857.

Wanner, H., Beer, J., Bütikofer, J., Crowley, T.J., Cubasch, U., Flückiger, J., Goosse, H., Grosjean, M., Joos, F., Kaplan, J.O., Küttel, M. Müller, S.A., Prentice, I.C., Solomina, O., Stocker, T.F., Tarasov, P., Wagner, M., and Widmann, M., 2008, Mid- to Late Holocene climate change: an overview. Quaternary Science Reviews, v. 27, pp. 1791-1828.

Weiss, H., 2014, The Northern Levant during the Intermediate Bronze Age: altered trajectories. In: Steiner, M.L., and Killebrew, A.E. (Eds.), The Oxford Handbook of the Archaeology of the Levant: c. 8000-332 BCE. Oxford University Press, Oxford, pp. 367-387.

Weiss, H., 2017, 4.2 ka BP Megadrought and the Akkadian Collapse. In: Weiss, H. (Ed.), Megadrought and Collapse. From Early Agriculture to Angkor. Oxford University Press, Oxford, pp. 93-160.

Wu, J.Y., Wang, Y.J., Cheng, H., Kong, X.G., and Liu, D.B., 2012, Stable isotope and trace element investigations of two contemporaneous annually-laminated stalagmites from northeastern China surrounding the "8.2 ka event". Climate of the Past, v. 8, pp. 1497-1507.

Yang, T.-N., Lee, T.-Q., Meyers, P.A., Song, S.-R., Kao, S.-J., Löwemark, L., Chen, R.-F., Chen, H.-F., Wei, K.-Y., Fan, C.-W., Shiau, L.-J., Chiang, H.-W., Chen, Y.-G., and Chen, M.-T., 2011, Variations in monsoon rainfall over the last $21 \mathrm{kyr}$ inferred from sedimentary organic matter in Tung-Yuan Pond, southern Taiwan. Quaternary Science Reviews, v. 30, pp. 3413-3422.

Zanchetta, G., Giraudi, C., Sulpizio, R., Magny, M., Drysdale, R.N., and Sadori, L., 2012, Constraining the onset of the Holocene "Neoglacial" over central Italy using tephra layers. Quaternary Research, v. 78, pp. pp. 236-247.

Zhang, C., and Mischke, S., 2009, A Lateglacial and Holocene lake record from the Nianbaoyeze Mountains and inferences of lake, glacier and climate evolution on the eastern Tibetan Plateau. Quaternary Science Reviews, v. 28, pp. 1970-1983.

Zielhofer, C., von Suchodoletz, H., Fletcher, W.J., Schneider, B., Dietze, E., Schlegel, M., Schepanski, K., Weninger, B., Mischke, S., and Mikdad, A., 2017, Millennial-scale fluctuations in Saharan dust supply across the decline of the African Humid Period. Quaternary Science Reviews, v. 171, 119-135.

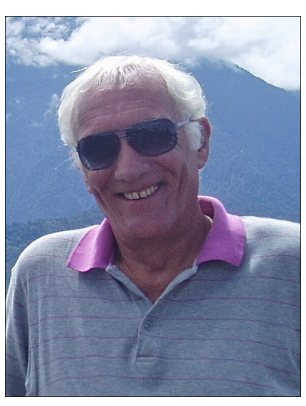

Mike Walker is Emeritus Professor of Quaternary Science, University of Wales, Lampeter, UK, and Honorary Professor, Aberystwyth University, UK. He is former President of the Quaternary Research Association of Great Britain, and past Chair of the Natural Environment Research Council Radiocarbon and Cosmogenic Isotopes committees. He chaired the SQS Working Group that defined the Pleistocene-Holocene boundary, and has recently chaired the SQS Working Group on the subdivision of the Holocene. His principal research interests are in late Quternary climate change and its manifestations in proxy records. He has worked extensively on problems of stratigraphy and chronology during the Last Termination.

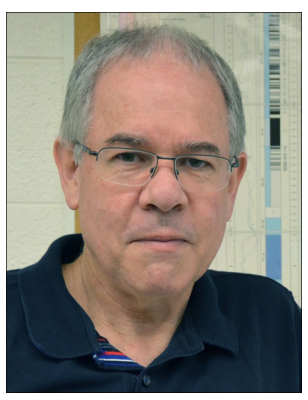

Martin J. Head is a Professor of Earth Sciences at Brock University, Canada, and former chair of his department. He was previously at the University of Cambridge, and before that the University of Toronto where he maintains an affiliation. He is serving a second term as Chair of the International Subcommission on Quaternary Stratigraphy (until 2020), is CoConvener of its Working Group on the LowerMiddle Pleistocene Subseries Boundary, and is a voting member of the International Subcommission on Stratigraphic Classification. Interests include late Cenozoic stratigraphy, paleoceanography, and marine palynology including the late Cenozoic record of dinoflagellate cysts and acritarchs.

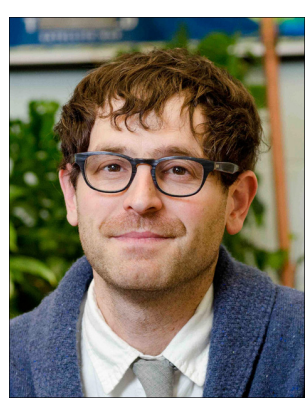

Max Berkelhammer is a professor of Earth and Environmental Sciences at University of Illinois at Chicago since 2014. Prior to this appointment, he was a postdoctoral research associate at the Cooperative Institute for Research in Environmental Sciences at University of Colorado, Boulder. He has been a visiting professor in the Geology Department at Colorado College and is currently an affiliate faculty at Oregon State University. His interests are in land surface-atmosphere interactions and land surface feedbacks onto the climate system in both a modern and paleo- context. He has worked on using modern analogs to better understand proxy records ranging from speleothems in India, ice core records from Greenland and sediment cores from North American lakes. He has a PhD from University of Southern California and a BA from Pomona College. 